\title{
EARLY MANITOBA BIRD NOTES
}

HAMILTON M. LAING, 1431 Comox Avenue, Comox, British Columbia V9N $3 Z 5$.

I was interested in birds very early in life and my interest never weakened. Here is my memory of the first birds that stuck. It was at Clearsprings, Manitoba, and they were a mystery for years. I was about three years old at the time and was walking hand in hand with my mother across what we always called the "Big Bridge" that spanned the coulee that separated the premises of the two Laing farms, Thomas and William - the latter my father. (They had taken up their land here side by side in the early 1870's.) From the bridge I spied seven or eight bright birds in a muddy pool left by the scrapers when the new road had been graded.

These pretty birds in the mudpuddle excited me. I noticed that about half of them were larger and more brightly colored than the others but my mother explained that that was the way of birds for the pappas to be big and brightly colored and the mammas to be smaller and tamer colored. But there was something wrong with the picture; pretty birds shouldn't be wading in dirty water even if they had black bills and feet. I wanted to watch these birds that were like no home birds, but my mother dragged me away.

It was 18 years later that, as a budding young ornithologist, I solved the problem of the pretty waders of the dirty water at the bridge. I was teaching my second rural school, the new Caronton school at Boissevain in 1905, not far from Whitewater Lake. On a spring day, wading the grassy shallows of the big lake (Whitewater), I stumbled on a little company of the beautiful waders that I had never forgotten. I must have broken records driving that bike home to reach my ornithological scripture: "Chapman's Color Key to North American Birds." I had my gun with me of course; all ornithologists of those days carried guns as well as field glasses and I had shot one of the largest and brightest birds. Wilson's Phalaropes, of course, and I made a drawing of the bird for my collection of field sketches and learned by dissection that my fine bird was a female well on the way to nesting! Later I found the species nesting in a pasture near my school. But I never trusted the ornithological judgment of my mother again!

Later in the season in my homemade boat near the middle of the big lake I encountered a flock of what I thought were sandpipers till I noted them swimming about nimbly and doing a lot of whirling as they seemed to be kicking some sort of food from the surface. The gun and my new text again solved their identity as Northern Phalaropes. I saw them many times later and always recognized them on the wing by their clicking notes. I never saw Northern Phalaropes in eastern Manitoba.

Wilson's Snipe. Never a common bird to me in eastern Manitoba at Clearsprings. So, rather strangely one morning about 1890 enroute to school, (which was one straight road mile from home) I heard a strange winnowing plaint repeated from the sky above the woods where the public road cut through the woods on the Jamieson property. I had a 
delightful bird puzzle to solve. How I did solve it I don't now recall but before long I knew it was a Wilson's Snipe giving his courting song and there must be a nest somewhere near. As nest finding now was my chief sport, I went through the wire fence and searched the little tamarac swamp examining the grassy hummocks. On my second try found a ground nest with four brownish eggs in it. In neither search did I see sight of any nest-owner. At my approach she must have sneaked off her nest and hidden. (I did not follow up the history of this nest.) I thought the eggs were large for so small a bird, but when I considered the large eggs of the Killdeer that I knew so well, I decided that large eggs were standard with Limicoline birds and let it go at that.

In my youth I never met any Manitoban sportsman who considered the Wilson's Snipe a good game bird worth the expenditure of ammo - not while there were three kinds of grouse, a lot of ducks and geese and two kinds of rabbits - the big prairie hare becoming plentiful and the snowshoe rabbit always available. I had to wait 50 -odd years and become a dyed-in-the-wool west-coaster to meet the snipe as a Canadian game bird. Two of my gunning Vancouver Island friends had discovered a snipe rendezvous and invited me in on a shoot. Because of his dodging flight I found him the most difficult of Canadian game birds to stop on the wing but when his plump little body came sizzling out of the oven he was tops. Later, during my work with the National Museum, I skinned a lot of the Wilson's Snipe's cousins and gave most of them the oven test.

Solitary Sandpiper. I met this sandpiper early in my life. He was in the east and west wherever there was a pool of stationary water. He was well named. I knew his voice from my bird-watching. He always protested loudly when disturbed. But I never saw a flock of his kind and I never saw his nest.

Greater Yellowlegs. I knew this big wader best in Manitoba from his behaviour when I saw him at prairie snow-water pools from the break-up of winter about April 1st. He was big and showy, loud of voice and he had a wonderful song, "Butler! Butler! Butler!" that travelled a mile. I saw him only in open country and, because of his long legs, he seemed a bigger bird than he really was. He was on the prairie long before my time and I looked on him as a big part of the spring but of small account in the migrant story of autumn. I never saw a real flock of his kind. Even at my best sandpiper beaches at Oak and Whitewater Lakes I never found him much of a figure in fall migration.

It was different with his small cousin, the Lesser Yellowlegs that was nearly always of importance in any wader gathering either spring or fall.

Killdeer. One of the original settlers of Clearsprings and common in southern Manitoba everywhere. At our place he arrived as soon as my father fenced the 30-acre holding field for the stock at night. Perhaps he liked the sound of the cowbell but more likely he was attracted to the area because the grass was always cropped short and there was always water available at one of the three blind springs where my father made the best one into a drinking place for the stock.

The killdeer hated grass and never used a blade of it or a twig at nest building. Instead, the female used a slight depression instinctively matching the ground with the color of Killdeer eggs and doing it so well that at 20 feet the "nest" was invisible to 


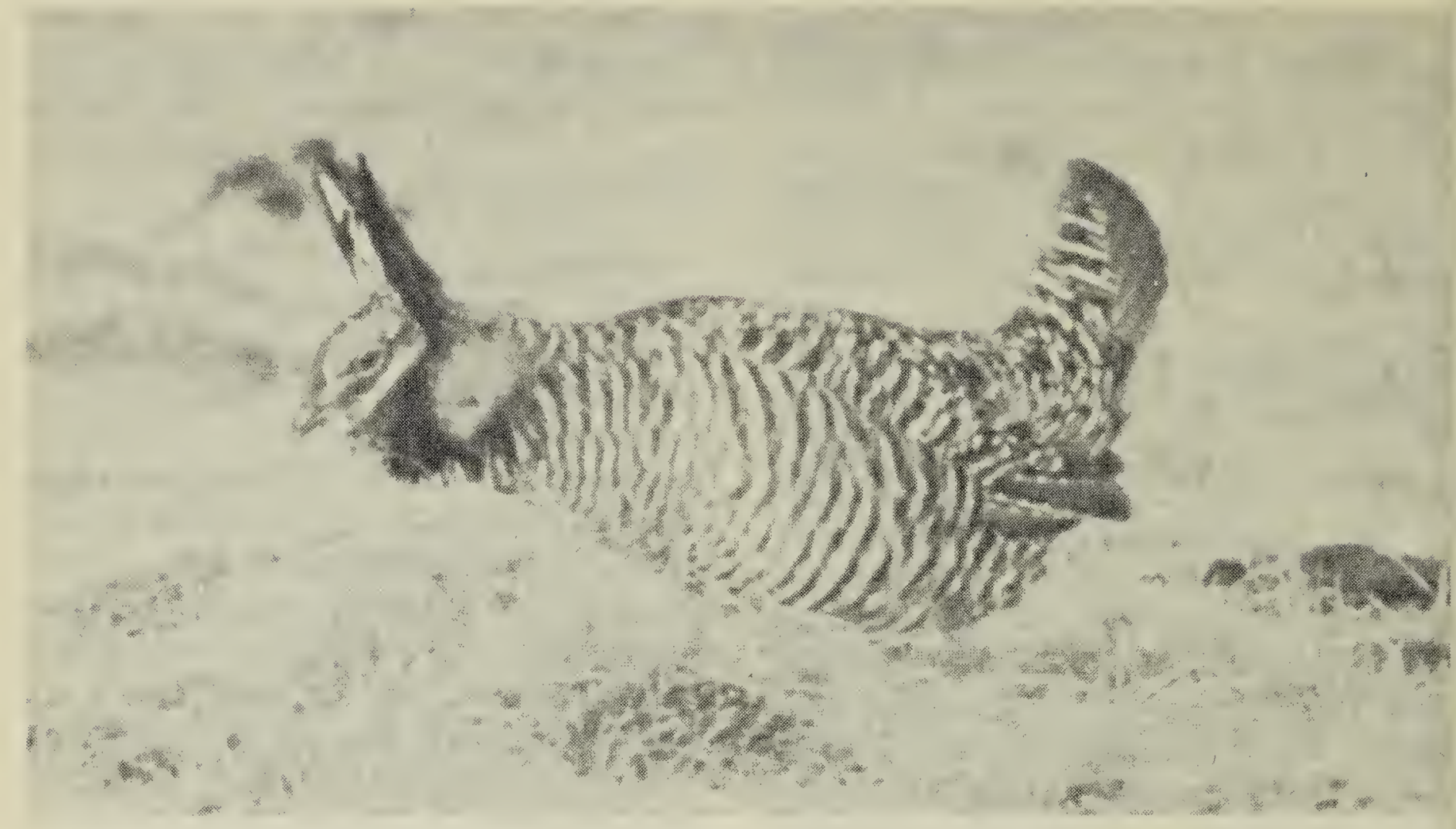

Greater Prairie Chicken (Pinnated Grouse)

Fred W. Lahrman

all but the sharpest eye. She had skill as well as talent, for her splendid wings could outfly any hawk of her neighborhood. She was also a talented actor and near her eggs would play the wounded bird act to perfection.

Pinnated Grouse. Like so many birds that followed settlement into the Canadian northwest, this one came early. My father had a story indicating its arrival to the Red River fields in Canada was in the early 1870's. Later when I had arrived and reached schooling age at 11 years, I found a good number of these new grouse in Clearsprings. But 1 also found that it was harder to put the new "Minnesota prairie chicken" into a game bag than it had been to bag the old-time Sharptail.

It was at Oak Lake and Whitewater Lake that I really met the new grouse in numbers. They loved the open meadows at both lakes and in spring kept the air lively with their breeding music. They really sang and whooped. At first they were mainly migratory and few remained to face the Manitoba winter. And they were always afraid of open water and at both lakes ganged up in good numbers in late autumn before going around the east or west ends. I have a negative that shows about 100 birds in a flock on the wing. The migratory movement was less observable in the spring when they came north in driblets in singles or two's and three's but flying high and direct like migrant ducks and geese. In spring at strutting time in the meadows they were very noisy and their humming songs and individual "Whoops" could be heard a mile. Their courtship antics were vastly different from those of the Sharptailed old-timers whose dances amused the first western explorers.

Passenger Pigeon. I am happy to be able to say that, though I was raised in Manitoba, I once saw Passenger Pigeons alive there. I cannot fix the date positively but it was before I was a diarist. I was walking with my father on the prairie road west of the woods on a spring day 
near where later Clearsprings school was located, when he suddenly exclaimed "Ho! Pigeons!" and approaching us from the south were a dozen or 15 large birds at perhaps 500 feet elevation. This flock was headed due north purposefully. My first surprise was that these birds were evenly spaced in flock formation like migrant geese or ducks and from what I had seen of domestic pigeons I thought that wild ones too would fly in a scatter. But I had not the shadow of a doubt about my father's judgment in the matter. In his nine years at Hemall, Ontario, he had been within seven miles of a big pigeon hatchery on the shore of Lake Huron and knew these birds well.

Mourning Dove. I was walking with my father also when I met my first Mourning Dove. The exact location of this meeting is now obscure. There is a section of rail fence involved and my parents had none such. We were close to this fence when there came a loud clatter of wings as five or six large birds burst up from the ground and two of them perched on the fence. "Turtle doves!" exclaimed my parent, probably using the nomenclature of Ontario, otherwise of Scotland for a small dove. It was the dove's first appearance though my father had now been in Clearsprings about 12 years. Both pigeon and dove records must be dated at about the same year. In neither case did I have a hankering for a gun. I was born in 1883 and at 11 years used both gun and rifle, so both these species (pigeon and dove) must be dated approximately 1890.

Once established, the Mourning Dove spread very rapidly. He seemed to like the sandhills. I found two nests there and another on top of a post. In 1911 when I forsook my boarding house and tented in a tiny poplar bluff on the edge of town, I had a pair of nesting doves close to my tent where the music of the male gave me a lot of pleasure. How these nests escaped the crows and Bronzed Grackles - eggers both - I never learned.

Turkey Vulture. In the 28 years that I lived in Manitoba the vulture was a very rare bird in both east and west. In the Red River Valley I saw the species only once. I don't believe that I confused the buzzard on the wing with any of the big, broad-winged hawks for the vulture has a cut of his own in the air and a flight of his own. I think it was 1893, the year that I had taken over my share of the stable chores, that I saw my first Turkey Vulture. We had lost a horse and instead of getting out the shovels to bury Dobbin decently, someone hatched the wacky idea that we could cremate the carcass with an unwanted wheat-straw pile in the stable-yard - kill two birds with the same stone.

So faithful old Dobbin's remains were dragged out on the prairie 300 yards from the buildings and a rackful of straw followed that made a terrific blaze. Result: we failed utterly; and after a week of summer weather there was an effluvium rising from that mound of blackened carrion that I'm sure was unmatched in the county. That the Laings were not asphyxiated was due entirely to the fact that a north-east wind was a rarity there. From the stable I kept daily watch to see what I hoped for: that the abundant crows of the neighborhood would develop a taste for underdone horse meat; but not even once did I see crows pay any attention to such fancy food while grasshoppers were in good supply. But one evening just before I left the stable when I took a last look out over our own grisly cremation, my eye was captivated by a big black bump atop the carcass and a second hard look said "Buz- 


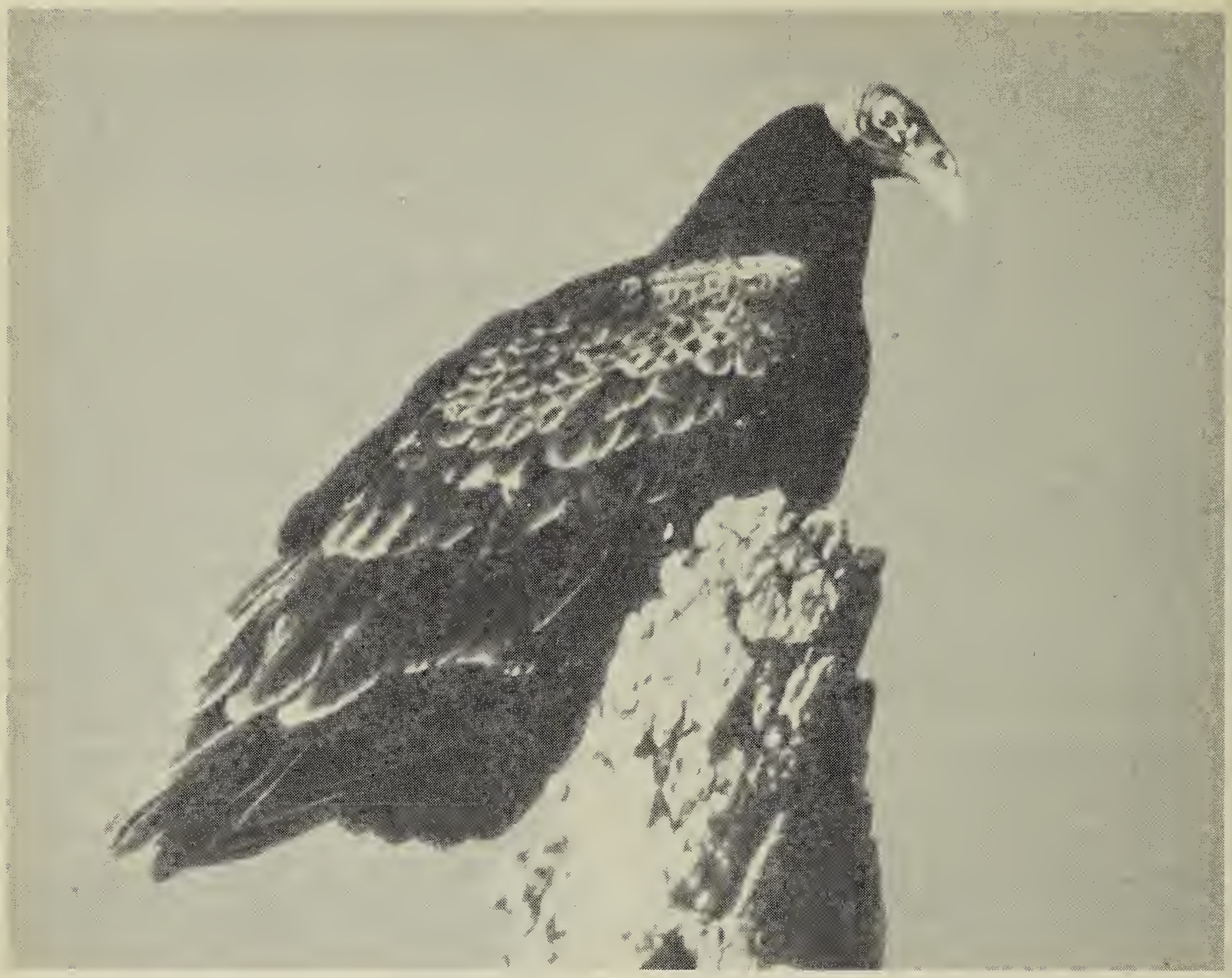

zard! Vulture!" I knew from pictures that our visitor was none other, and my first. The visitor was not making a meal as I hoped, but sitting immobile as though enjoying the smell.

To my great disappointment my Turkey Vulture did not return and the question that filled my head was: how in a region that had no vultures did this bird locate the bait that drew him to Clearsprings? And there seemed only one answer: the vulture must have had a marvellously keen sense of smell that drew him an unconscionable distance. It wasn't a case of his riding herd on other birds that were using the carcass. He discovered it through his own talent.

Marsh Hawk. In early Manitoba days he was an original and I think the first predatory bird I learned about. He was a common early neighbor at Clearsprings but more common at Oak Lake where he roamed over a much wider range. He came early in spring among the first arrivals at the break-up of winter's snow and mainly left early in autumn when his main food, mice and other small mammals were denning up for the winter. In my youth I was more familiar with the Marsh Hawk than with any other hawk. Our grassy coulee system was his hunting ground for mice through much of the year. He hunted there while on the wing and dropped on them; his long slender legs and feet were competent grabbers.

Before I was of much use on a dairy farm I was an eager bird-nester and by watching to see where the male hawk packed his plunder. I dis- 
covered a nest not far from our stables. It was half hidden in the brush on a knoll just across the road 200 yards off. When I reported the nest to my father he said to keep away from it. But I had to have one good look at that nest - a slovenly matting of grass and some twigs. My father had seen his hawk neighbor packing home Franklin's Ground Squirrels which to Laings were mild pests. The varmint insisted on living with us and persisted in spite of the fact that my father usually answered his ringing whistle with a shot from his Remington rifle.

In 1894 when I was first allowed to use the rifle, I polished up my growing skill as executioner also. My mother detested the "dirty little beast" because one dug under the lowest $\log$ of the milk-house and sampled the cream in all the row of cooling pans - which was hitting my mother where it hurt. This, of course, was before we got the Artesian well to raise the cream on our milk cans. My father had a hearty respect for the Marsh Hawk because, though he nested almost in our midst, he never showed any interest in our poultry, which is more than can be said for several other species of Manitoba hawks.

It was at Oak Lake that I got my most intimate knowledge of the species. I learned first why he was a "marsh" hawk and why he was a "harrier". He loved the marshes and Oak Lake was surrounded by big deep marshes on three sides. These were a far-famed breeding ground for a lengthy list of marsh birds. And in the days that I camped at the lake in sight of these marshes there was scarcely a day of the breeding season that I did not see the Marsh Hawk harrying some weaker birds and being himself harried by a union of stronger birds, ganged up to drive him from the area.
The main lake drained through Plum Creek into two big marshes that were homes to two big colonies of Franklin's Gulls and a daily sight was a dozen of these little gulls, fighting mad trying to drive the intruder from their home area. What took him to the marsh in the first case? The answer seemed easy and it all boiled down to the sad fact that in the breeding season of marsh birds, Circus gave up the chase after tough little mammals to feed his young on the tender young of his marsh neighbors. Plainly no young bird hatched on his range could expect to reach flight unless his parents were strong enough to defend him or, in the case of small birds, cunning enough to keep him hidden. I found one Marsh Hawk's nest in some willows on the lake shore less than half a mile from the nearest Franklin Gull colony. There was method in this.

At Oak Lake I saw another side of Circus not observed elsewhere. The few marsh hawks that were about the marshes in late September and through October were linked up with the shooting fraternity and knew what they were doing. In my judgment it was now that this cassius of the predatory birds found the fattest living of his year - in northern marshes. The shot gun, even in the best of hands, is a wounding weapon. After every lodge shoot there was almost bound to be a wounded Canvasback too tough for either man or dog to retrieve; or a Mallard hard hit that made half a mile on the lake to drop dead and drift ashore. Cassius knew all about this. For him, who normally worked hard for a living, this wasteage of the gunners was apple pie with whipped cream on it for the dessert of a hard year. Around the lakeshore there were patches of feathers on the drifted Pondweed rolls where he had digested a grainfed mallard. He was never the epicure and his wide range of food 
covered toads and frogs and garter snakes as well as small mammals. In hard times he was not above a touch of carrion and this gift of the gunners was far above the level of a dead hen on our manure-pile on which he had once dined.

Sharp-shinned Hawk. Another original, but never common at any of my stations in early years - commonest at times of migration when they travelled with their commissary, the small birds, and gave them a rough time. The species probably nested in some of the poplar bluffs at Clearsprings and some wooded stations westward but I never caught him at it. For long in my early years I did not know his book name and called him the "darter" because of his sudden flushes of speed after small birds. I have seen the Sharpshinned Hawk take prey oftener than any other hawk. Three or four times I have rescued sparrows from his clutches that, when released, flew-off more scared than hurt. This is not the deadly grasp of the falcon, Pigeon Hawk or Sparrow Hawk. But very early I learned of his dexterity at killing small birds though I never saw him interested in a mouse or other small mammals.

Once while I was enjoying my swing hung in the balsam poplars half way between house and stable I caught the Sharp-shinned trying his luck for day-old chicks right beside me. The valiant old Plymouth Rock mother was putting up a splendid defense for her charges, protesting vocally and jumping up to meet his every strike and pecking wickedly at him till I came dashing to the rescue. It was the only time I saw a Sharpshin interested in our poultry.

Early though in my bird studies I learned of the Sharp-shin's deadliness concerning the small birds that seemed entirely his sole source of food. Three or four times I saw the slow-winged Song Sparrow in his clutches and in another case shot the hawk while in possession of a dead Purple Finch. Once I saw him nab a junco on the wing. which he seemed to do very easily. Several times at the beaches at time of migration I saw him in hot pursuit of sandpipers, but I feel that his luck with sandpipers was rather low. When attacked the piper flock bunched closely and flew "at top speed". To attempt to grab a bird from such a blizzard of speeding missiles was really a dangerous game and I never saw a Sharp-shin fool enough to risk his wings trying it.

Once while I was at my Manitoba Oak Lake camp, I was out in the Henderson pasture at the big slough standing holding my binocs to identify two passing migrant finches. I had just decided on goldfinches when a big female Sharp-shin came from somewhere, swept into my focus and struck at them. They too foiled the attack by a vertical dodge. The hawk renewed the attack three or four times and each time was outmaneuvered. She could out-fly the goldfinches but not out-dodge them and after about four failures withdrew from the action and went on her way. Perhaps she had already dined. To me it looked like sour grapes.

Red-tailed Hawk. Another of the originals at Clearsprings but never noted nesting there, perhaps because his food, Richardson's Ground Squirrel of the western wheat fields was not found east of the Red River and the Franklin's Ground Squirrel, though common enough, being a "scrub gopher," was much harder to catch. At Boissevain I saw least of the Red-tail. Perhaps this was because of the scarcity of nesting timber and also because the wheat farmers poisoned their ground squirrels. It was at Glenora and Oak Lake that I got readily acquainted 
with this "gopher hawk", as he was often called. He was common, particularly at Oak Lake, where a lot of wasteland produced a healthy crop of three species of ground squirrel, despite the poisoning campaigns of the graingrowers, and nesting grounds were in abundance. He had the timbered valley of the Assiniboine River and two or three ranges of sandhills with scrubby poplars big enough for nest sites. Also the abundant oak timber of the lake shore was a favorite nesting place. In 1921 when I finished my season's field work for the National Museum at Oak Lake, I found two forms of the Red-tailed Hawk there: the normal brown bird nesting in river (Assiniboine) timber and the pale, whitish race (Krider's) nesting in the sandhills but also in the oaks at the lake, and I took specimens of both for my field catalogue.

In my experience these Red-tailed, broad-winged hawks were not the small mammal killers some naturalists would have us believe. I never climbed to an Oak Lake Redtail's nest that did not show plenty of feathers of both ducks and grouse. In one low nest (Krider's) I examined in the nearby sandhills I found two freshly killed downy Sharp-tailed Grouse chicks and I thought it very likely that the two young Red-tail's in the nest already had breakfasted on other chicks from the same covey. I have a lot of notes on Red-tail food but, as they apply mainly to Vancouver Island conditions, I must pass them up here with the statement that the food list of the Red-tail is much more expansive even than that of the Marsh Hawk. I have heard the Redtail charged with killing domestic poultry, likely when times were hard, but only once did I see him concerned with the Laing fowl. That day he came into the barnyard and perched on a post close to the cow stable. He seemed to be trying to size up what to do with so much good living when I fired my first shot from father's rifle at him - and missed and felt terrible.

Broad-winged Hawk. In only two places did I get acquainted with the little Broad-winged Hawk: Clearsprings and Oak Lake. He loved timber and plenty of water. At Clearsprings I saw little of him until the breeding season was over. Then I met him on my way to school at the fenced McCaskell woods and learned his sharp call that seemed to be dead in his throat through most of his time in the north. His was a short acquaintance, for he came late in the spring and left early in autumn. I associated his voice with early fall. As I never saw him molesting a small bird or being chased I decided he must be a frog-eater getting his nourishment from the coulee on the north side of the woods. There was a good frog population along the creeklet from the Big Spring and another good breeding pool for both toads and frogs below the Big Bridge on the road.

Only once did the Broad-wing show any interest in our poultry and that was on a day near fall migration about 1890 when a Broad-wing brought his family to our stable yard and set in to scare livers loose in the fowl that had been fed in the barnyard. The hawk visitors circled low, seemingly enjoying the confusion they produced. Perhaps a Broadwing had a sense of humor and enjoyed the sight of two obese Plymouth Rock biddies trying to get home through the slide entry at the same time, or of well-grown cockerels high-tailing to the woods for cover and safety. The hawks kept up the game till my mother caught on, grew frantic and rushed to my father for support. This sort of circus with fowl didn't look good for egg production or Thanksgiving 
marketing of cockerels. Do something! Father was at his work bench. He put down his tools, strode into the kitchen and came out with the double-barrelled shotgun that some one had loaned him as he never had one of his own. There was a mean glint in his eye that the hawks couldn't see and when the first rouser came in range the gun boomed and sent the bird spinning down into the potato patch.

I was not a bit sorry. It was before I was allowed to shoot and it gave me my first chance to examine first-hand a young-of-the-year Broad-wing. Whatever their game meant, that shot put a sudden end to it.

Whatever knowledge I later acquired of the Broad-wing life history was acquired at Oak Lake in 1907 and later. Plainly he liked the oaks on the shore of the big lake. I think two pairs nested in the oaks though I never climbed to more than one nest. Again in early September his young were circling with him in the blue and his sharp note: "Stik-e-e-e!" was the plainest bird voice on Oak Island. Henderson who owned the island and did some farming on it, told me the "little hawks" did not bother his poultry; only the "big hawks" did, meaning, of course, the Goshawk and perhaps the odd Red-tail.

That is why one morning I stopped so suddenly on the road down the island when, about opposite the Henderson barn, I found myself within short range of a young Broadwinged standing beside the mangled remains of a young cockerel about 6 feet off the wheel-track and 10 feet from me. I said "Shoo!" and raised my hand. He raised his wings quickly and then slowly put them down again. He was loaded to his plimsoll, incapable of flight and he knew it. There may be a half dozen solutions to this unusual broad-wing behavior. Mine is that the cockerel got bumped off by a commuter's Model T, the hawk saw the accident and his opportunity, tried to pack off the victim but because it was beyond his own weight only jerked it away from the wheel track. Then quite naturally he overtaxed his capacity. Your guess may be as good as mine.

Goshawk. At the latitude of southern Manitoba the Goshawk was met rarely except in late autumn or winter. He was the only hawk that had an abiding interest in the rural poultry yard. He was just naturally a killer. Though all across Canada his chief food was birds of the grouse kind which he hunted relentlessly as well as the snowshoe rabbit (hare), he killed a lot of smaller birds also. And he had his own way of doing it. One collecting season in good Goshawk range in northern Alberta taught me the Goshawk's method of capture. He is a pouncer. No eyespying from tall perches like the broad-winged raptors. No flying it down by sheer wing-power like the falcons do. Though superb on the wing, he pins his faith on the element of surprise, dodging the skirts of the poplar bluffs and cutting through them. Keeping at low elevation, he either pins an unsuspecting victim to the ground or hits him in the middle of a slow start. If rabbits are plentiful, he kills more of them than he does of winged prey.

But though most farmers with poultry had lost a bout or two to the "chicken hawks", if you had shown them an adult Goshawk in the blue plumage, they wouldn't have known what it was. It was the young firstyear birds in the brown plumage that did most of the predation; and as there is considerable sex difference in the sizes - as in all hawks - it was the big efficient female that was the commonest predator.

I have only one good Goshawk predation story of the Laing poultry 
yard and it happened before my time. One day while my father was in the stable yard, a goshawk - that probably had made his stalk through the windbreak poplars close at hand - pounced on a lusty Plymouth Rock hen. I suspect the attacker was a small male and plainly it was a case of biting off more than he could chew. The squawking biddie dragged her aggressor through the fowl slide-hole in the door with her and my father was not slow about closing the slide and going in with a club.

Bald Eagle. In my prairie years a very rare bird. For my Clearsprings years I have only one memory note and it could never be forgotten. It was in the spring of about 1890 before it was my morning chore to take the Laing brothers' combined herds to pasture, while I was enroute to Clearsprings School. I was near the cross road when I saw a sight that moved me deeply. Near the corner of my uncle's farm there was a large plot of natural prairie that he always cut for hay and beyond it at about a third of a mile a patch of woods that escaped early prairie fires and the poplars had grown to veritable giants. On the limb of a big tree a goodly distance from its top sat the biggest wild bird I had ever seen. I stood and stared. And just as though it had been staged for my benefit, the great bird leaned forward and launched at me. Even at the distance I could hear the great wings as they bashed and broke some dead limbs in his way. For a scary second I felt that he was coming to attack me, till I saw he was rising slightly, leaving his night roost I fancied, and he passed me at a hundred yards where now, at closer quarters, he showed a gleaming head and tail whiter than snow.

When I told my father about my magnificent feathered giant he said: "Boy, you saw a Bald Eagle!" And he said a lot more on the subject that

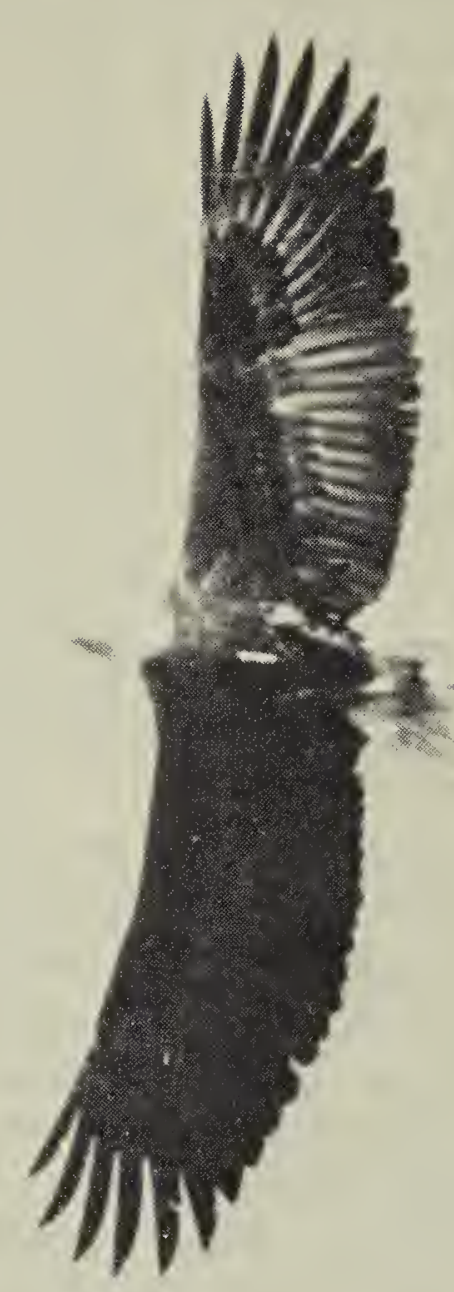

Bald Eagle.

Wayne Lynch

considerably deflated my wonderful bird with a chat on emblems. He indicated that our Uncle Sam could not have been choosey when he took the big lunk as emblem of a great country - a raptor that in his living habits was about half vulture.

That I had not noted the bird previously was largely because the big bird had left the central plains with the Indians and Buffalo. But there was still room enough for him in the north and this one, my first acquaintance, was on his way. I felt likely we would meet again. We did. In my second year of teaching at Glenora, Manitoba, my spring bird list of migration mentions another Baldy passing northward on a nonstop ticket. I have no more Manitoba Bald Eagle notes. 
Golden Eagle. Personally, in Manitoba I had little contact with the Golden Eagle. He was a rare bird and only a winter visitor to the southern part of the province. I never saw a Golden to know it in Clearsprings. In my morgue of early bird sketches there is a drawing of an adult specimen sent to me by A. A. Alford, M.D. The bird was caught by his father, Robert Alford of Oak Lake, who in winter often ran some lynx traps along the Assiniboine River about a mile from his home. This dated 15 February, 1908, when I wintered in Winnipeg.

My live contacts were few. Once in my Oak Lake years during a winter day's prowl I saw 2 big raptorial birds at the river woods, that by all the rules I knew should have been Golden Eagles but the fact that both birds showed a lot of white, knocked me dizzy. I did not know then that this was normal for young Goldens of the year.

My closest contact must have been at Boissevain when I was visiting the Whitewater Lake's wonderful island in 1905. It was August and I had stripped native and waded the big Sexton Slough to the woods on the southeastern side. Had the island all to myself, though I had a lot of noisy company in the Blackcrowned Night Heron. Hidden in the shrubbery I was studying the projecting muddy point, loaded with ducks of several ages and breeds when, with no warning, a huge brown raptorial visitor dropped from the sky aiming to pin down a duck dinner. Hell broke loose! There was a roar as every duck and half-grown ducklet tried to get to deep water at the same time. The water boiled as the intruder darted here and there trying to grab a victim. But in the confusion he failed and, on realizing it, gave up this assault and winged out of sight in the Manitoba maples. Though it was early to expect a visit from a Golden Eagle, this may have been a visitor from the Riding Mountains. No later experience made me change my mind. This was early autumn, 1905, when the lake water was at a very high level.

Black-billed Cuckoo. This was one of my early birds of Clearsprings but a bird to be heard and not seen. He was not a bird of small woods. I never heard his melancholy "Cowcow-cowing" in our poplar windbreak but always from the distant big woods beyond the coulee. He might have remained just a voice and mystery had not my father put me wise to him. I suspect he learned about this secretive neighbor in Ontario. This cuckoo was present at Glenora in 1901 and 1902 as just a distant voice from the timber near my boarding house, but entirely absent on the Boissevain prairie. I got really acquainted with him at Oak Lake island when he came and neighbored with me. When his solemn chant came from the woods a hundred yards from Heart's Desire (my summer camp) - I knew it was my time and I hunted till I found his nest. He didn't stick around and abuse me as many birds do. Both birds kept out of sight. But I knew it was a cuckoo's nest because it was unlike that of any other bird of the neighborhood. It was built in a hawthorn clump less than three feet from the ground and, although it held eggs, I didn't make note of the number or color and memory doesn't serve. I was afraid this secretive bird might leave her nest if she knew it had been discovered. When after a good wait in which the male kept silent, I visited the nest again, it contained two bristly young which I pronounced the ugliest fledglings I had ever seen.

Sparrow Hawk. On reaching Comox, B.C., 1 July 1922, we found 
the Sparrow Hawk an old friend of the roadside wherever there was a bit of used pasturage to keep the grass short. He was never so numerous in Manitoba in my young days there. A beautiful hoverer; but that is not the way of a falcon and when I found that on Vancouver Island he hovered for grasshoppers and seldom if ever for anything else, he lost caste. I never saw him with a mouse or other small mammal - anywhere. I never knew him to winter in Manitoba but a few always winter in coastal B.C. where I can keep an eye on him and I fear that it is the poor little slow-winged junco that pays his meat bill. Once in early spring at Glenora, Manitoba, as I was standing enjoying the sight of a little flock of juncos just arrived, a Sparrow Hawk suddenly dropped like a stone in their midst. He missed the target only.by inches, but instead of picking a victim and flying it down as a real falcon would do, he made no further attempt. At Comox in winter several times I have seen him with captured juncos.

At my Oak Lake, Manitoba camp, in the pasture near the big slough one day I saw two Goldfinches, plainly migrants, south-going, where there was no cover whatever, attacked by a supposedly hungry Sparrow Hawk. He could outfly them but at every strike the intended victim beat him by a lightning-like vertical dodge. After about four strikes that failed, the hawk gave up and went off to other business with an air that said he didn't like the taste of Goldfinch anyhow!

Short-eared Owl. When I was a boy I got acquainted early with the Short-eared Owl as his hunting ground was the coulee quarter section and often he did his hunting not far from my home. I then called him the "prairie owl" as he seemed to have nothing to do with cover as most other owls do. He was com- monest at Oak Lake because there was more uncultivated land there. But in my folio of early drawings, before I started saving specimens, I have a sketch of a Short-ear taken in 1905 at Boissevain, 21 October, from the prairie north slope of Turtle Mountain - the cultivated side. A few days earlier I had played a game with him and I just had to see the outward mechanism of that marvellous ear.

I was waiting in a stooked wheat field for a Mallard duck flight and just at sunset a Short-ear took off over the field in that bouncing flight that always seemed to say that he had too much wing for his small body, At my decoy squeak he started confidently on a bid for a mouse meal. It was not the usual thing for him to hunt among shocks but he seemed to know what he was doing. At about 100 yards I pursed my lips and gave him the mouse squeak I had used successfully to decoy a prairie fox or coyote or other mouser. He reacted instantly on his beat, turned and came on a bee line for my shock. I hunkered down, hid my face and then didn't move a muscle. His direction finder was working 100 percent. And now 3 or 4 feet above my head he shouted "Mouse!" - this from a bird I had thought voiceless!

I waited a while and then tried him with another mouse squeak when he was in another part of the field and he did his part of the act at twice the distance. But when I tried him at an incredible distance he showed that he heard me by a nervous little start and then acted: "No, not three times!" and went on with the business of getting a real mouse meal. I was now glad no ducks had come for I had learned about the magic ears of Asio flammeus.

Long-eared Owl. I have probably only one record of this small owl before 1903 when I spent the year 


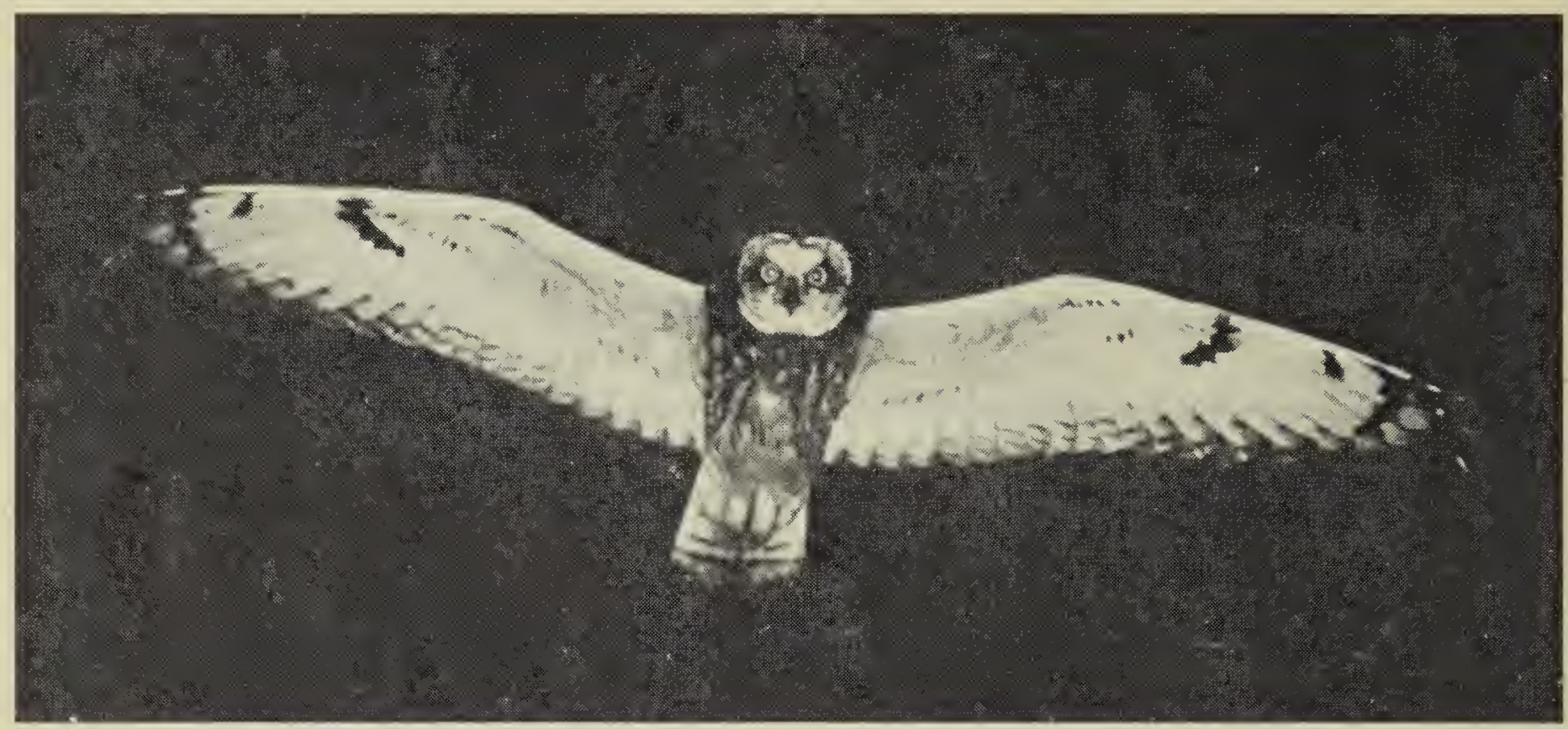

Short-eared OwI

Fred W. Lahrman

rural teaching (Runnymede) at Oak Lake and.was surprised to find the species common there. Previously, about 1893, one morning I found a small brown owl in Clearsprings sitting on our house. What intrigued one was the length of his "horns". These ear-tufts were long and slender. He was far too small for a Great Horned Owl which by now I was well acquainted with; and the Screech Owl, though "horned", was not known then in Manitoba. But at Oak Lake in 1907 the Long-ear was the commonest of the small owls and perhaps the least known for I never saw him hunting. I found without exception that he used an old crow's nest to raise his family, never to my knowledge building nest of his very own. He also showed a strong preference for the nest in a willowclump.

I decided that crow-nesting was rather an owlish trait as the Horned Owl too did it sometimes. But the old terror of the woods had a fair excuse. He was such an early nester that he wanted to be building while the best nest-material was still often under snow. He showed good sense in using crow architecture only a year old. I located one Long-ear's nest at the very edge of town on the sandhill side. It became a habit with me while on the prowl to examine all crownests for a pair of long ear-tufts, usually plain, if present, above a flattened derelict structure. Some of the Long-ear nests were quite low and I got some good snapshots of the fledglings but none of the parent birds. When interviewed the young had a comical way of stretching erect to their utmost length, trying to make themselves look like something they were not.

Great Grey Owl. A winter visitor only to the southern part of Manitoba - possibly visiting the Turtle Mountains in the southwest as it did to Clearsprings in the south-east. One winter day in 1895 - dated, as it was my first winter to use a shot gun my cousin William Laing and I were hunting Snowshoe Rabbits in my father's "Big Bush" south of my home. We kept about 30 yards apart - each of us that way being more or less "dog" for the other - and suddenly I spotted a big grey bump in a tree above Bill's head that resolved into a big owl that was show- 
ing more interest in Bill than fear of him. I fired at once and dropped the bird almost on my cousin's head.

It was the first Great Grey Owl I had ever handled. I mounted this bird, getting some help from a small treatise on taxidermy among my father's books, sending to Winnipeg for the glass eyes and wondering how come so big a bird could do with such small peepers. My mother gave this prize away to a city friend who admired it. She didn't like stuffed birds at large in the house because they collected dust but couldn't stand dusting.

I think it was a year later that one evening, looking across the coulee, I saw a dark bump in a willow-clump of the light timber leading away from my uncle's barnyard. That called for immediate investigation, and gun in hand, I raced across the Big Bridge and up the Tom Laing driveway intending to start a stalk from their horse stable. I had just reached the stable yard gate when there he was - as expected, winging toward me across the stable yard, a big floppity owl - when there came a gunshot and the visitor dropped. My cousin Tom had beaten me to the stalk. But he verified the fact that while I was hurrying over the grade I had heard a single, strong hoot from the location of that owl. He too had heard it before the owl took wing.

Richardson's Owl. I also have some notes on the tiniest member of this interesting family. On 6 November 1906, a winter I was spending in study and living at the new Winnipeg home of my parents, one morning I spied a tiny owl close to our front door not more than 10 feet above the sidewalk of Carlton Street. He was perched in a shade tree but, of course, at the date there was no leafage and he was very plain. I had every opportunity for obser- vation of the tiny, round-headed, robin-sized member of his tribe and no hesitancy in calling him Richardson's Owl or "Boreal Owl" of the 1957 AOU Check-list. I saw him leave his day perch in the evening when he winged over to the little Carlton Street Park, but I suspect he was lost in the city and would not survive.

I have another record of this tiny northerner lost in civilization when on 5 January 1901, I picked up a dead specimen of the same species in the machine shed of the Fraser farm when I taught the Glenora rural school. Plainly this visitor had died of starvation during record December cold weather. From this bird in hand and the memory of the Winnipeg visitor I made sketches for my folio of new birds.

Hawk Owl. A very rare mediumsized owl in the latitude covered by most of my bird notes. In 1903 in early autumn, my first year of teaching rural Runnymede school at Oak Lake, someone shot a Hawk Owl, mistaking it for a hawk. This is an easy mistake because, although in hand, dead, this bird does show some owlish propensities, in the air he is a Peregrine Falcon. Knowing my interest in birds he sent the bird to me. But he did not give it to me as he wanted to have it mounted, and so now I have no drawing of it in my "morgue" and find no details of it in my diary. The same fall in late November and early December I got 2 weeks holidays for a moose hunt in the Riding Mountains, Manitoba. I didn't get a moose, but I met the Hawk Owl at home almost daily and learned something of its hawk-like habits. For one thing, it made a lot more day noise than most owls do.

Burrowing Owl. A misnomer; he should have been named "Burrows" owl and I suspect that in Manitoba he 


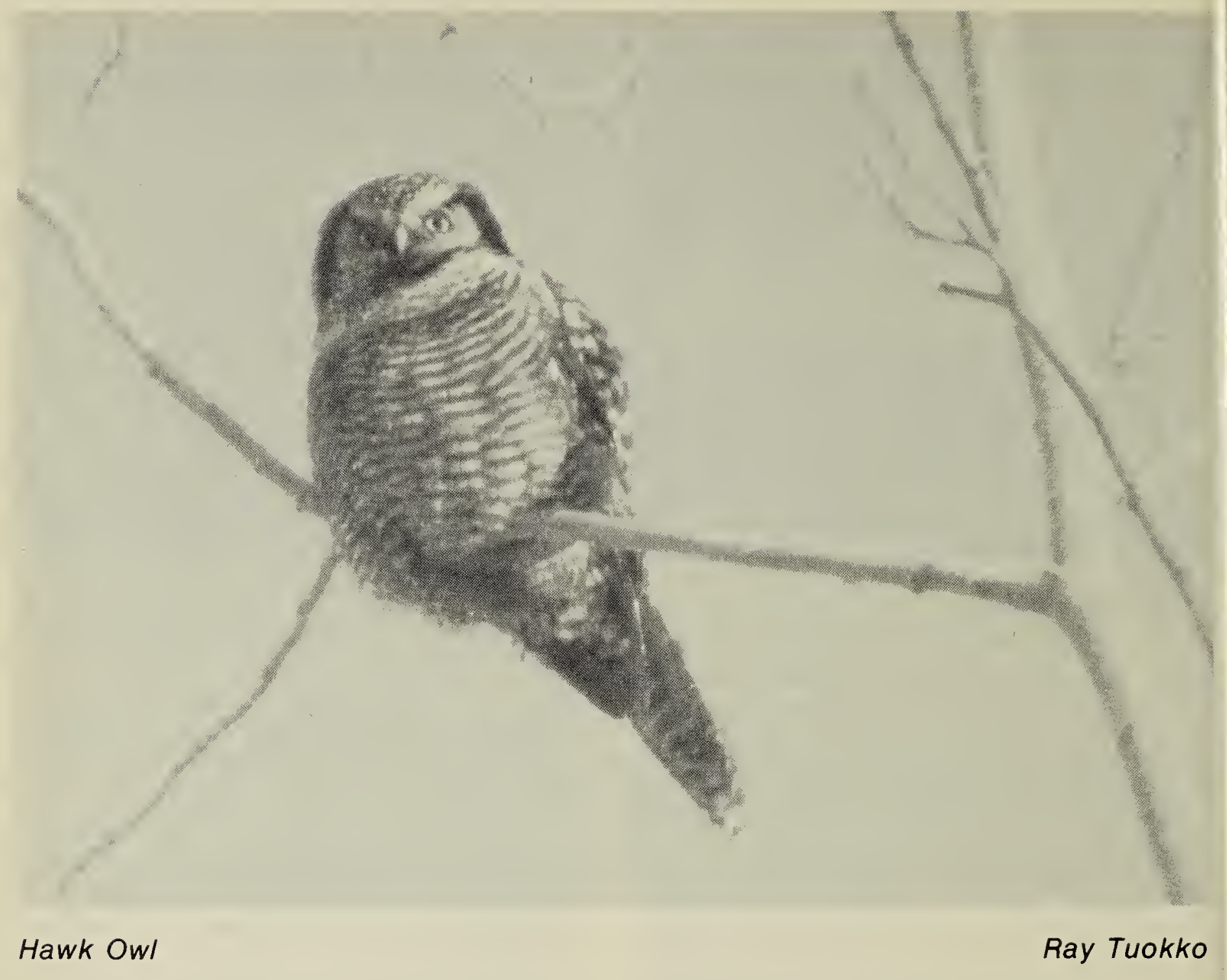

cannot be dated as he was a satellite of the Richardson's Ground Squirrel, so common on the western plains in the Buffalo days and chief food of the Badger that dug him out for a living and in so doing left snug burrows for the little owls that cannot dig for themselves.

The little ground owl was likely more numerous in the Buffalo days than later. As soon as the homesteader blackened the broad acreage of grassy plains to grow wheat, he poisoned off his ground squirrels, and filled the Badger holes and so made life impossible for the owls. It is possible that some of the ground owls did cross east of the Red River before my time. Buffalo skulls were common trash in Clearsprings and boggy ground was full of their bones. The scrub-grown knolls along the coulee were riddled with Badger holes where the "scrubgophers" (Franklin's Ground Squirrels) had been dug out. But the settler as a rule made short work of the Badger. His big holes in cultivation were intolerable and his winter pelt was a valuable fur.

So there were no Burrowing Owls in my time at Clearsprings nor did I find any sign of them on the Glenora prairie. I met my first ground owlet at Boissevain in 1904 when the hired man at the Frank Latimer farm where I boarded brought home a young ground owl with a load of gravel from a pit several miles distant. The wellgrown owlet had been exposed when a breakdown at the pit had made him homeless. He was a very tractable little codger but very noisy which we cured to some extent by feeding him "worms" of lean, fresh meat till Dave took him back to his home pit next 
day and made a new hole for him. We hoped for the best.

At Oak Lake in 1903, in regard to ground owls, the reverse was true. We found the Burrowing Owl in possession of a lot of territory. He was on the Robert Alford farm three miles east of town. A farmer north of the Assiniboine River claimed a family. He was also on a wide stretch south of the town and ranged a good long way west up the Pipestone Creek country. Young Robert Alford, senior class student, showed me some splendid pictures he had taken with the old camera equipment I had turned over to him when I invested in something newer. This was over an area of mixed farming not like the Boissevain wheat country. There was room for some interesting little owls that seemed breeding successfully everywhere. There was a lot of sandy land, breeding gophers, little poisoning was done and large families of both gophers and little owls were the rule. It would not have been a surprise to me to find the owls feeding young gophers to their own young. The temptation must have been strong!

Screech Owl. In the spring of 1921, I had my first Manitoba adventure with an Eastern Screech Owl. After my spring work with Taverner for the National Museum on the Saskatchewan prairies at the end of June, he gave me an option as to where I would like to spend my remaining three months of service on the prairies. I chose Oak Lake, Manitoba, because I knew it to be a very interesting region biologically and I had already sampled it some while teaching there. I had scarcely driven my tent pegs again at the old campsite I called "Heart's Desire" when I found a local biological problem waiting for me. Something was very vocal at nights to disturb the sleep of the local campers. As yet no one had seen the author, though most listeners were agreed on it being some sort of bird, but who ever heard a bird like that at a time birds should have the head under the wing? There seemed a feeling in the air that now that a bird man was on the scene, he should solve it.

But he had to hear it properly first, and in my first two nights in my camp the disturbance drifted faintly on the night air from the far east end of the road that ran down the campers' island. What I could make of it so distantly was that it was a high pitched whinny of a dozen or so notes that, beginning high, running rapidly down to a much lower key at ending - one straight exclamation. Nothing soto voce - it had power. I could whistle a fair imitation of it. I was doing so to company in camp when suddenly a bright light flared in my think-tank. "Why that bird is making the call that Dr. Sutton made when he tried to decoy the Comox, B.C., Screech Owl out of the health camp, and failed and I had to show him how!! The Semple-Sutton duo from Pittsburg had worked on Comox ornithology a year earlier.

We were sitting by a tiny excuse for a campfire in the light of the camp lamp when I whistled a few calls in an exhibition of what I would try next when a visitor suddenly exclaimed, "There he is!" and pointed behind me, I turned in time only to see the maple leaves twiddling. Our visitor had come, taken a look and beat it. My human visitor said he had seen a little owl.

Well I couldn't fail now. Next evening I went much farther down the road before I turned my whistled whinny on the air. I got a reply first try; a little owl came and I got a shot and carried to camp what I figured was the first Manitoba specimen of a Screech Owl. The eastern form of course. In Oregon and Comox, B.C. I 
had been playing with the Kennicott, west coastal form, evidently quite a different bird in its habits.

Woodpeckers. On reading my early Manitoba bird records, one might be led to think I had a crush on the birds of the owl tribe, but this would not be true. I have told about things pretty much as they happened and Manitoba was rich in owls. I have really much more regard for the busy hard-working woodpeckers. The preservers and house-carpenters of the woods, bringing death to woodborers, not to weaker neighbors of flesh and blood. And here are two fine woodpeckers I met in the winter of 1903 when I visited the Riding Mountains. A new small sized woodpecker with an all black back sent me scurrying to my bird guide. The Arctic Three-toed Woodpecker, never seen by me farther south. And here too I met the Cock-of-theWoods (Pileated Woodpecker), the huge, handsome near crow-sized woodpecker that my father had met in the woods of Ontario but never in Manitoba. Little then did I think that one day he would be my neighbor in Vancouver Island woods starting great echoes and raising his noisy family in a home chopped from a big alder by the creek, a stone's throw from my little barn where at milking time I could always count on a rumpus while the young were in the nest. In song season the big fellow can be heard half a mile or more and strangely he sings the same songs as the Red-shafted Flicker and many good bird watchers get fooled by this. I am not sure about the pitch but the big fellow invariably drops the last note of his even roll; the flicker does not.

My first Manitoba Scarlet Tanager dates 10 May 1905, Boissevain, when I was the teacher in Caronton rural school. The William Latimer home, at which the Manitoba maples were well grown and a popular calling place for migratory birds, was close to the school and son Wilford on seeing the brilliant bird migrant, shot it and laid it on my school table. This tanager was a good example of that vast migration of eastern birds moving into the northwest. Ten years later Scarlet Tanagers were common tenants of prairie wind-breaks. As I was not then saving specimens, I made a sketch for my "morgue" and stuffed the bird, a present for Wilford.

Redpoll. An interesting little winter neighbor was the Redpoll; but I should put it in the plural for two reasons: no one ever saw a redpoll alone and because in the southern migrations of these northerners, the two species combined. This conduct is not common as most birds in migration prefer to travel in flocks of their own kind. There are good reasons for this. I met my first redpolls in Clearsprings where at first spring blackening of the yard a flock enroute north would drop in for weed seeds; or perhaps they joined the snowflakes before the granary door where my father threw the weedseeds from the fanning mill. I may have met the species at Glenora, but I saw none on the Boissevain prairie and it was Oak Lake that provided me with most redpoll experiences. A mile east of the town along the CPR railroad track was an old, abandoned field between the track and the sandhills that still grew an annual crop of weeds, mostly tall-stemmed, that were not buried under winter's snow. There was cover enough for shelter in the willow-clumps and light timber in the sandhills nearby; and the place must have had everything the redpoll heart desired, for a flock always wintered there. Also it was right on the course of one of my after 


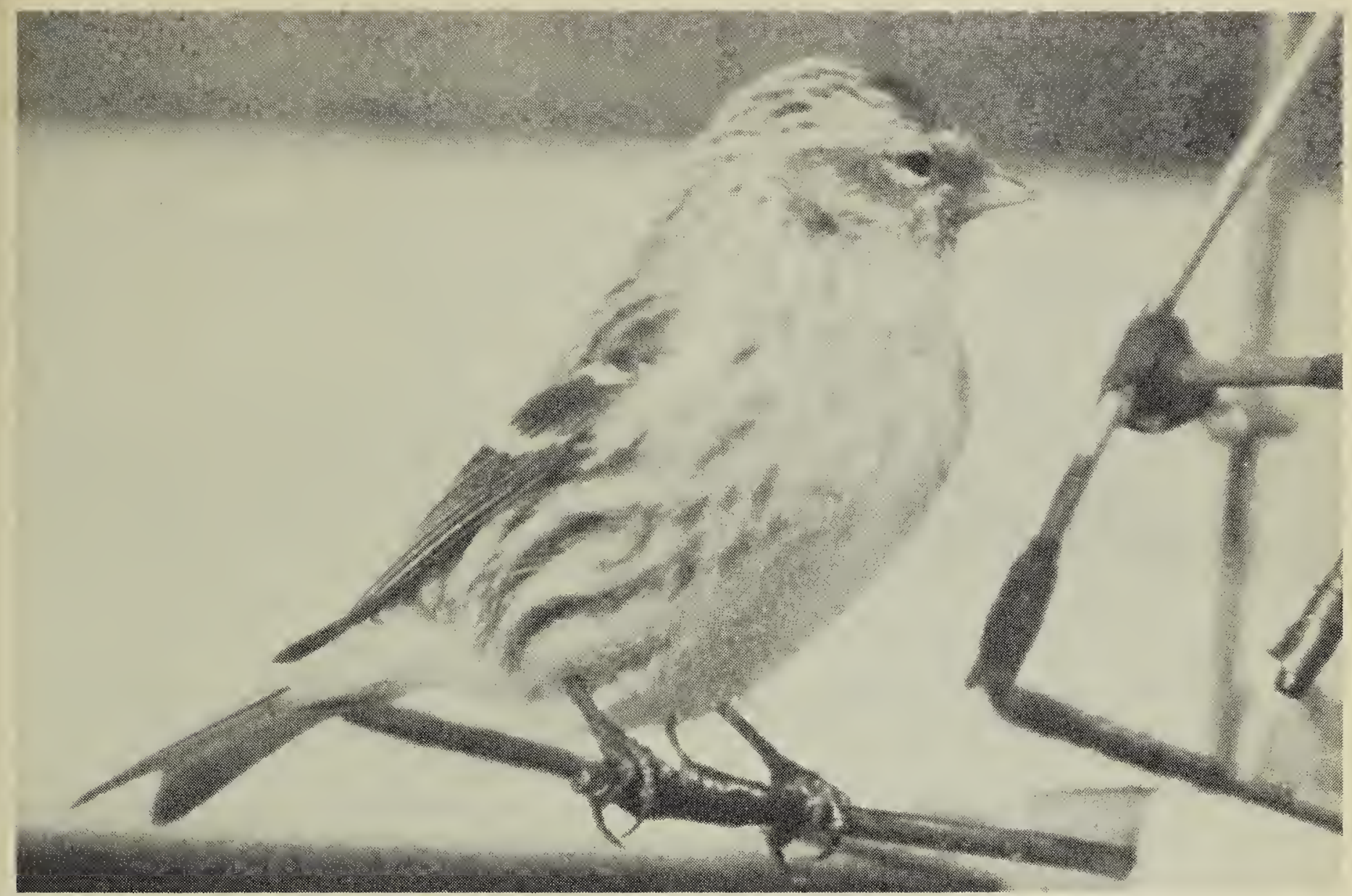

Common Redpoll

Lorne Scott

duty walks which were a regular part of my life then.

One trait of redpoll life was a thing that greatly pleased me. This was his musical heart. He was the only winter bird that really sang at this season. As the sun rose higher and grew stronger, the Black-capped Chickadee would sing his stingy two-note song: "Spring soon!" and the Tree Sparrow might chuckle musically a bit. But Acanthis flammea took music seriously and put on the air a full scale orchestra and gave a heart-warming chorus.

I was always interested too in glassing the flock for some of their blond cousins, the Hoary Redpoll. And never disappointed. They mixed perfectly. The redpolls of course were winter visitors only. I never saw one nest south of Lake Athabaska in northern Alberta.

From the scientific point of view I had a very successful four months at my old camp ground at Oak Lake. I suspect the abundance of oak timber there had an effect on the bird life. At that time I found the following birds not seen or taken elsewhere: Krider's Red-tail, Richardson's Merlin, Eastern Pigeon Hawk, Western Pigeon Hawk, Western Kingbird, Say's Phoebe, Mountain Bluebird, Ferruginous Hawk as well as small doubtful fry of warblers and sparrows.

I was lucky to have friends to help me. One was Miss Edna Burns, the star student of my class in nature, when I taught high school in Oak Lake Intermediate town school. Now she had a little cabin at the lake, also a fliver and took an interest in getting me into new fields that I could not reach on foot. It was through Edna on a trip to Hartney one afternoon that I added the Mountain Bluebird and Say's Phoebe to my list. For my new Ferruginous Rough-legged Hawk my thanks went to another old friend, 
Wm. Beveridge, local school inspector living in Virden who, on Saturdays, was apt to show me new fields and this trip into the Pipestone country was lucky.

I had another young friend, Herman Battersby, early teenage, very interested in my work. Herman lived a couple miles off across the sloughs eastward on a farm and was a born naturalist if ever there was such. There was a road across the sloughs and often after work at night Herman drove the family car over to my camp to see my damage of the day. One evening in early dusk as I was returning to camp on the road where it is closest to the lakeshore, something jumped in the roadside grass that I first thought a frog but quickly saw it was not. I gave chase by hand and when I had grabbed the mouse and squeezed it safe I found I had my first Manitoba Pouched Mouse. I had never seen one before. I was gloating over it in the camp lamp when Herman arrived and I showed him my treasure. To my dismay he was not a bit excited. "Yes", he said, "they are around. l'll get a couple for you. l've plowed out two or three". And later he did get them. And with them he gave me advice on where to set to catch the long-tailed jumping mice. "Try the nettle patches!" he said.

When I tackled the story of early Manitoba bird records I had not given much consideration to the size of the subject. A great number of birds altered their way of life to conform to the human settlement of a vast continent. That the human conquest of the North American continent ran northwestward and the bird conquest did the same is, of course, significant but the physical shape of the continent compelled it. The Great Lakes and the Hudson Bay's mighty central thrust from the
Arctic accounted for that. Though I had a dozen record-book sized diaries and more than 20 shirtpocket-sized miniatures of field notes to work with, covering about 85 years of a long and active life afield, I can touch lightly on but a few bird species.

\section{HAMILTON MACK LAING}

H. M. Laing must surely be Western Canada's oldest living naturalist. Born in 1883, he grew up near the present site of Steinbach, Manitoba, and then taught school at Oak Lake, Manitoba. There he took Manitoba's first specimen of the Western Kingbird and wrote a 249page book, Out with the Birds, published by the Outing Publishing Company of New York, based on his bird observations at Oak Lake.

In 1920 he was a naturalist with Francis Harper's expedition to Lake Athabasca, and in 1921 he was with P. A. Taverner in the Cypress Hills area. These were his only major studies in Saskatchewan.

Early in 1969, I began correspondence with him, and asked whether he could write some of his reminiscences of bird study in the Prairie Provinces. He told how busy he was keeping in his house and garden, felling trees and cleaning up the beach of his ocean property at Comox, British Columbia, remarkably hale and hearty. He wrote long and interesting letters, and as the years went by he kept physically active to a degree not expected for a man of his age.

The material published here was hand written from memory and with occasional reference to notebooks, when Laing was 96 years of age. C. S. Houston. 